\title{
А.Ю. Серегина
}

\section{ЖИЗНЕОПИСАНИЕ АЕАИ ФОЛКАЕНА: БИОГРАФИЯ ИЛИ ИСТОРИЯ ОБРАЩЕНИЯ?}

КАючевЫЕ СЛовА: Э^изабет Кэри, Аюси Кэри, история обращения, биография, английские католики XVII в., английские монастыри в НидерманАах.

АннотАция: Статья предваряет первый русский перевоА "Жизнеописания меди ФолкленА", написанного в середине XVII в. монахинями английского бенедиктинского монастыря в Камбре (сестрами Кэри) и повествующего о жизни их матери, Элизабет Кэри, виконтессы ФолкленА - переводчицы, поэтессы и полемистки, а также и обращенной катомички. Автор приходит к выводу, что "Жизнеописание" сочетает в себе черты биографии и истории обращения, а описанные в тексте обращения - самой меди Фолкленд и ее Аетей - попадают в категорию так называемых "интемектуальных обращений" через чтение книг и теологические Аебаты. "Интемлектуальные обращения" считались уделом мужчин. ОАнако сестры Кэри использовали эту модель Аля утверждения своего положения внутри сообщества монахинь Камбре, известных своими интемлектуальными интересами. Кроме того, авторы "Жизнеописания" показывали, что интемлектуальная деятельность матери вела к обращению Аругих в католичество, что тем самым делало ее миссионером - по сути, если не по названию.

Жизнь леди Фолкленд давно привлекала к себе внимание и современников в XVII в., историков и за отделяющие нас от ее смерти столетия уже не раз становилась предметом исследования. Это и неудивительно, ведь Элизабет Кэри, виконтесса Фолкленд необычна по любым меркам: дама, по рождению и браку принадлежавшая к кругу елизаветинских придворных, но позднее входившая в ближний круг королевы Генриетты Марии и одновременно - друзей герцога Бе-

Анна Юрьевна Серегина, А.и.н., в.н.с. ОтАеления историко-теоретических исследований ИВИ РАН, aseregina@mail.ru

DOI: 10.32608/2307-8383-2021-29-265-281 
кингэма, блестяще образованная для своего времени женщина, писавшая поэмы, исторические и полемические сочинения; первая англичанка, опубликовавшая свою пьесу, обращенная католичка.

Сочинениям Элизабет Кэри и ей самой посвящено немало работ, а пик исследовательского интереса приходится на конец XX - начало XXI в. и вписывается в контекст гендерных исследований в области истории религии и литературы ${ }^{1}$. Все они опираются на ее биографию, написанную в середине XVII в. документ столь же необычный, как и женщина, которой он посвящен. «Жизнеописание леди Фолкленд», составленное ее дочерью-монахиней в 1640-х гг. для сестер обители в Камбре, являло собой пример сочинения неопределенного статуса, какими изобилуют архивы женских монастырей: с одной стороны, эта биография не предназначалась для издания (и была впервые опубликована только в XIX в.); с другой, исторические и биографические сочинения, хранившиеся в монастырях, имели устойчивую, постоянно воспроизводившуюся читательскую аудиторию, превышавшую непосредственных друзей и родственников автора, т.е. адресатов частного документа, обладая, таким образом, и некоей долей публичности ${ }^{2}$. Но прежде всего, это текст, написанный женщиной о женщине и для женщин.

Элизабет Кэри (урожд. Тэнфилд, 1585-1639) 3 была единственной дочерью и наследницей сэра Лоренса Тэнфилда $^{4}$ (ок. 1551-1625), джентльмена из Оксфордшира, сделавшего блестящую юридическую карьеру: начав выступать в

1 Обзор основных работ, посвященных Элизабет Кэри и ее сочинениям CM.: Wolfe. 2006.

2 Серегина. 2011; Серегина. 2021: 130-147.

3 Hodgson-Wright. 2004. См. также: Серегина. 2003; Серегина. 2018.

4 Carlysle, Ibbetson. 2004. 


\section{Серегина А.Ю. Жизнеописание леди Фолкленд}

суде в качестве адвоката (барристера) в 1579 г., он стал одним из судей Королевской скамьи (1606), а в 1607 г. - главным судьей Суда Казначейства. Продвижению по службе способствовали связи жены: Элизабет (урожд. Саймондс, 1560 ок. 1595) была дочерью богатого норфолкского дворянина, Джайлса Саймондса, и племянницей сэра Генри Лй, елизаветинского придворного (чемпиона королевы ${ }^{6}$ ) и управляющего королевским манором Вудсток в Оксфордшире.

Элизабет была единственной дочерью и наследницей сэра Лоренса, который, видимо, за неимением наследника мужского пола, поощрял ее выраженный интерес к чтению, к немалому раздражению матери (а затем - и мачехи, Элизабет Эванс [ум. 1629]). Девушка прекрасно владела французским языком, а также выучила испанский, итальянский, латынь и даже «трансильванский» (вероятно, венгерский) у некоего «трансильванца, которого встретила в доме отца. Кроме того, она интересовалась богословскими трудами, читала отцов церкви, Кальвина и Ричарда Хукера и многих других. Интеллектуальные запросы Элизабет кажутся удивительными, но стоит иметь в виду, что семья предназначала ее для придворной карьеры, а среди придворных дам образование ценилось. В 1602 г. ее выдали замуж за сэра Генри Кэри (1576-1633)7. Отец мужа, сэр Эдвард Кэри, был двоюродным братом лорда-камергера, барона Хансдона (кузена самой королевы Елизаветы), а в число родственников вхо-

5 Fernie. 2004.

6 Чемпион короля/королевы - придворная Аолжность, восходящая к первым годам после нормандского завоевания. Во время коронации нового монарха чемпион бросал вызов ^юбому, кто Аерзнул бы оспорить право его господина/госпожи на корону. При Елизавете I ее чемпион каждый гоА устраива^ турниры, посвященные Аню ее восшествия на престол (17 ноября).

7 Kelsey. 2004. 
дили елизаветинские придворные династии: Денни, Пикеринги, Ниветты и др.

Генри Кэри получил хорошее образование в Грей Инне и в Оксфорде, а затем, как многие молодые дворяне, отправился проявлять свою доблесть на поле боя: он служил в Ирландии, где его в 1599 г. возвел в рыцарское достоинство граф Эссекс, во Франции и в Нидерландах. Занимал он и заметное положение при дворе, став джентльменом королевской опочивальни (при Якове I), хранителем королевских драгоценностей (эту должность он фактически унаследовал, заняв ее после отца и деда с материнской стороны, сэра Генри Ниветта). Но настоящий взлет карьеры Генри Кэри приходится на период доминирования при английском дворе герцога Бекингэма, в клиентеле которого принадлежал Кэри: в 1617 г. он был назначен распорядителем (comptroller) королевского двора и членом Тайного Совета, в 1620 г. получил титул виконта Фолкленда (в Шотландии), а в 1622 г. отправился в Ирландию в качестве представителя короля (lord-deputy). Жена последовала за ним в Дублин. За годы брака Элизабет стала матерью одиннадцати детей - шести дочерей и пяти сыновей: Кэтрин (1609-1625) ${ }^{8}$; Люсиуса (1610-1643); Лоренса (1613-1642); Виктории (1614-1694)ㅎ Энн (16151693); Эдварда (р. и ум. 1616); Элизабет (1617-1683); Люси (1619-1650); Мэри (1622-1693); Патрика (1624-1656); Генри (1625-1656?).

8 Брак Кэтрин с Ажеймсом, графом Хоумом (ум. 1633) был устроен самим королем Яковом І, а венчание состоялось в Уайтхоме в мае 1622 г.: Chamberlain. 1939: 437.

9 Уже после смерти матери, в 1640 г. Виктория Кэри вышла замуж за казначея мичных покоев короля Карла І, сэра Уильяма ЮвАейла (15811652). 


\section{Серегина А.Ю. Жизнеописание леди Фолкленд}

В 1625 г. Элизабет Кэри обратилась в католичество, что привело к разрыву отношений с мужем и отцом. Леди Элизабет пришлось жить щедротами друзей, а также старшего сына, унаследовавшего в 1625 г. имущество деда. После смерти отца Люсиус Кэри, второй виконт Фолкленд, выделил матери подобающее ее рангу содержание и предоставил ее опеке сестер и (на некоторое время) младших братьев, которых Элизабет довольно быстро обратила в свою веру. Умерла Элизабет Кэри в 1639 г. и была похоронена в капелле королевы Генриетты-Марии в Сомерсет-хаусе.

Интеллектуальные интересы леди Фолкленд, сыгравшие свою роль при обращении в католичество, проявились в ее творчестве. Помимо несохранившихся стихов, Элизабет Кэри была автором пьес - не дошедшей до нас драмы, действие которой происходило на Сицилии, и «Трагедии Мириам, царицы евреев» - первого написанного женщиной драматического произведения, опубликованного в Англии (1613 г. ${ }^{10}$. Кроме того, перу Элизабет Кэри принадлежала полемическая «История короля Эдуарда II» (1626/1627 гг., издана в 1680 г.)11 - политический комментарий к современным событиям, т.е. к борьбе парламентской оппозиции с королевским фаворитом, герцогом Бэкингэмом, а также стихотворные жития святых, переводы полемических произведений кардинала дю Перрона (1630 г.) ${ }^{12}$ и собственные полемические сочинения (не изданы; рукопись уничтожена по требованию сына).

Подробности жизни виконтессы Фолкленд известны нам из ее биографии. «Жизнь Элизабет Кэри, леди Фолкленд» со-

10 Cary. 1613.

11 Cary. 1680.

12 Cary. 1630. 
хранилась в единственной рукописи из Лилльского архива (куда она попала вместе с другими документами из бенедиктинской женской обители Камбре). Ее первое издание вышло в 1861 г.13, а в 1994 и 2001 гг. появились новые публикации ${ }^{14}$. Рукопись датируется 1643-1649 гг. и принадлежит перу одной из дочерей главной героини, Энн или Люси Кэри. Долгое время исследователи не могли прийти к единому мнению относительно авторства, однако последняя публикация биографии указывает на наличие одного автора и нескольких редакторов. Наиболее вероятным автором сейчас считают Люси Кэри, а редакторами были ее брат Патрик, а также две или даже все три сестры - монахини, и прежде всего, Энн ${ }^{15}$.

Элизабет (в монашестве Августина, 1617-1682), Люси (в монашестве Магдалена, 1619-1650) и Мэри (в монашестве Винифрида, 1621-1693) вместе со старшей сестрой Энн (в монашестве Клеменция, 1615-1671) были обращены в католичество своей матерью в 1634 г., ${ }^{16}$ причем в этом процессе сыграли свою роль и наставления самой леди Фолкленд, так и ее капеллана - бенедиктинца Джона (в монашестве Катберта) Ферсдона17. Последний сыграл в роли детей Кэри важную роль: благодаря ему виконтесса выбрала именно орден бенедиктинцев для своих детей. Кроме того, Ферсдон был связан узами патроната с влиятельными католическими семьями юга Англии, включая виконтов Монтегю. Он был одним из группы монахов-бенедиктинцев, которых регуляр-

13 Simpson. 1861.

14 Weller, Ferguson. 1994; Wolfe, 2001.

15 Wolfe. 2001: 46.

16 Биографии сестер Кэри приводятся по Аанным онлайн портала: Who were the Nuns? A Prosopographical study of the English Convents in exile 16001800 [Queen Mary's College, University of London], https://wwtn.history.qmul.ac.uk/. Cм. также: Wolfe. 2004. Cooper, Bellenger. 2004. 


\section{Серегина А.Ю. Жизнеописание леди Фолкленд}

но принимал в своем доме второй виконт Монтегю. В 1627 г. именно Ферсдон перевел с латинского языка на английский опубликованную в Сент-Омере биографию леди Магдален Монтегю18 - первое пост-реформационное жизнеописание благочестивой католички, за которым последовали и другие. Вполне вероятно, что Ферсдон привлек внимание сестер Кэри к этому труду, тем самым заронив в них идею составить жизнеописание их матери.

После обращения девушек по приказу короля отняли у матери и отправили к старшему брату Люсиусу, остававшемуся протестантом, несмотря на все старания матери. Впрочем, виконт Фолкленд отличался удивительной для XVII в. веротерпимостью и не просто позволил сестрам уехать из Англии и стать монахинями, но и внес вступительный вклад за каждую из них. Сначала, летом 1638 г., уехали три младшие сестры. Энн Кэри была фрейлиной королевы Генриетты-Марии, и ее семья явно рассчитывала, что девушка останется на родине и вступит в брак. Однако Энн предпочла иной путь и в 1639 г. последовала за сестрами. Все они принесли монашеский обет в 1640 г. Элизабет и Люси прожили всю оставшуюся жизнь в Камбре; Энн и Мэри Кэри в 1651 г. отправились в Париж, где основали новую обитель. Мэри вскоре вернулась оттуда «домой», в Камбре, а Энн осталась в Париже, став келарницей нового монастыря. Смерть Люси и отъезд двух сестер в Париж и составляют хронологическую границу написания биографии леди Фолкленд: текст был составлен, когда все сестры еще жили вместе в одной обители.

Биография леди Фолкленд выделяется из числа других: все прочие жизнеописания благочестивых католичек XVI XVII вв. были написаны не членами семьи, а духовниками -

Серегина. 2017: 215-216. 
мужчинами и по жанру близки либо к «мартирии» («Жизнь Маргарет Клитроу»), либо к надгробной проповеди (жизнеописания Магдален Монтегю, графини Эрендел, Дороти Лаусон) ${ }^{19}$. Хотя по своей форме «Жизнь Элизабет Кэри» тяготеет именно к последней группе, в ней есть черты, сближающие ее с биографией. Достаточно отметить внимание к семейным делам (естественное для дочери, но не для исповедника), к отношениям между родственниками, довольно легко прочитывающиеся авторские оценки «героев» - членов собственной семьи (так, свою бабушку, мать Элизабет, автор явно недолюбливает и не вполне уместно, с точки зрения жанра, упоминает ее тщеславие, сухость и черствость по отношению к мужу и единственной дочери). К отцу автор относится с иронией, которая порой переносится и на мать, но в гораздо более мягких формах.

При этом жанр сочинения невозможно определить однозначно, как это часто случалось с авторами - мужчинами и женщинами - не получившими формального (латинского) образования. Последняя особенность проявляется во всем тексте, выдавая неопытного автора: в нем слишком длинные абзацы, синтаксис излишне усложнен, имена упоминаются так редко, что читатель то и дело путается в местоимениях, переставая понимать, о ком именно идет речь.

Каждый текст такого рода имеет свои жанровые особенности и функции. Зачем сестры Кэри создали биографию своей матери? Исследовавшая это сочинение Х. Волф обращает внимание на объем заключенного в нем автобиографического материала: почти половина текста на самом деле не о матери монахинь, а об их собственном обращении. Х. Волф полагает, что к написанию текста Люси Кэри побудила 


\section{Серегина А.Ю. Жизнеописание леди Фолкленд}

жизнь в монастыре Камбре. Монахини и духовники этой обители часто составляли (авто)биографические сочинения, так что труд сестер Кэри встраивался в уже существовавшую традицию. Кроме того, автобиографические вставки (история обращения сестер и их - а в особенности Люси - взаимоотношений с матерью) служили средством самопознания, покаяния и искупления грехов юности, т.е., играли важную роль в духовной жизни монахинь 20.

Необходимо, однако, помнить и о еще одном важном жанре литературы раннего Нового времени, который повлиял на текст биографии гораздо сильнее, на наш взгляд. Многочисленные и весьма распространенные в XVII столетии (авто)биографические повествования были посвящены обращению главного героя или героини в «истинную веру» и чаще всего представляли собой сочетание разных видов и моделей «историй обращения» 21 . История Элизабет, представленная в тексте, - это, прежде всего, история обращения: матери и самих авторов и редакторов биографии. Ведь не только леди Фолкленд, но и шесть из десяти ее детей стали католиками. Обращение же требовало доказательства истинности избранной веры, а также и конструирования новой идентичности внутри вновь обретенного конфессионального сообщества ${ }^{22}$. Причем если сама леди Фолкленд, обратившись в католичество, осталась в Англии, сохранив дружеские связи и поддержку покровителей, то ее детям пришлось труднее: все они покинули страну и, переехав в Камбре, вступили в бенедиктинский орден. Англичане - члены монашеских общин за пределами родины в большинстве своем

20 Wolfe. 1998: 8-10.

21 Murray. 2009; Conversions. 2017; Shinn. 2018.

22 Rieske. 2015. 
происходили из семей, поколениями хранивших верность католичеству, и гордились таким родством. Сестрам Кэри требовалось найти свое место в сообществе эмигрантов, показав себя и свою семью истинными католиками, несмотря на относительную «свежесть» их обращения.

Подобная апология представляется необходимой, если учесть, куда именно попали сестры Кэри. Женский бенедиктинский монастырь Камбре был основан в 1623 г. как дочерняя обитель Брюссельского монастыря - старейшего среди английских женских общин «за морем» (с 1599 г.), отличавшегося также своим составом: монахини принадлежали к знатнейшим (и богатейшим, что определялось размером вступительного вклада) католическим семействам Англии. Обитель Камбре была скромнее, однако и она могла похвастаться связями - причем ее покровители были не просто влиятельными людьми, но и принадлежали к «духовной элите» английского католического сообщества: основана обитель была семьей Мор (потомками Томаса Мора, уже тогда, задолго до официальной канонизации, почитавшегося как святого). Его праправнучка Хелен (в монашестве - Гертруда) Мор была одной из сестер-основательниц ${ }^{23}$. Находясь в такой обители, сестры Кэри явно чувствовали необходимость обосновать важность заслуг их матери перед английскими католиками, защищая и свое собственное право находиться в обители Камбре и играть важную роль в жизни общины и конфессионального сообщества в целом.

Необходимо также отметить, что обращения леди Фолкленд, ее дочерей и даже юных сыновей в католичество описываются в соответствии с моделью интеллектуальных обращений, которая обычно применялась к образованным 


\section{Серегина А.Ю. Жизнеописание леди Фолкленд}

мужчинам, и чаще всего к клирикам 24 . Сама Элизабет Кэри приходит к осознанию истинности католического учения через чтение книг, причем ее, в отличие от дочерей и сыновей, никто в этом чтении не направляет. Ее духовный путь следует схеме: чтение - сомнения - советы богословов кризис веры - обращение, который обычно воспроизводился в апологиях представителей католического или протестантского духовенства. Дочери шли примерно таким же путем; основным отличием является внимание, уделенное беседам с наставниками и богословами и соблазнам на пути к истинной вере. Примечательно, что соблазны здесь - не зов плоти и мирские радости, они тоже интеллектуальны, а в роли искусителя выступает богослов-антитринитарий Уильям Чиллингворт. В биографии много места уделено дебатам Чилингворта и иезуита Холланда, а дамы семейства Кэри предстают в качестве взыскательной аудитории.

Почему сестрам было так важно подчеркнуть интеллектуальную составляющую обращения - своего собственного и матери? Ответ на этот вопрос тесно связан с тем, как женщины понимали и представляли на страницах своих сочинений собственное место в католическом сообществе и свой опыт деятельного благочестия. Английским католичкам XVII в. было свойственно представление собственной религиозной жизни через образ мученицы за веру. Конечно, реальных мучениц, претерпевших мучения во имя католической церкви в Англии раннего Нового времен, было совсем немного - в XVI в., на пике елизаветинских гонений, были казнены всего три католички, а в XVII в. - ни одной. Тем не менее, многие подвергались арестам, допросам и тюремному заключению. Их биографы всегда стремились перечислить и описать слу-

24 Об обращении леди Фолклена см.: Серегина. 2021: 50-67. 
чаи столкновения с законом и протестантскими властями во имя веры. Подобные гонения свидетельствовали о добродетелях героинь. Именно поэтому в жизнеописании леди Фолкленд ее дочери подробно рассказали о допросах и ее поведении на них. Они были важными свидетельствами ее веры.

Образ мученицы имел и еще один важный аспект, значение которого в религиозной культуре английского католического сообщества обычно рассматривается лишь в отношении мужчин. Мученик за веру обычно не только страдал за нее: он также ее распространял - как своим примером, заставляющим свидетелей уверовать, так и своей проповедью. Ведь до мученической кончины многие из них были миссионерами. Связь мученичества и миссионерства подчеркивалась в произведениях авторов раннего Нового времени, прежде всего иезуитов, внушалась молодым студентам английских семинарий «за морем» и являлась отличительной чертой их религиозной культуры 25 .

Для английских католичек отсылка к мученичеству была не только (и не столько) свидетельством страданий за веру, сколько отражала стремление примерить на себя образ миссионера, наставника. Это желание вполне объяснимо, если учесть ту важную роль, какую женщины играли в религиозном образовании внутри своей общины, а также в обращении родственников и друзей в католичество. Однако европейская культура раннего Нового времени не имела в своем распоряжении моделей и образов, позволявших описывать как нормативные и положительные активные действия женщин в религиозной сфере - их активное социальное служение, как сказали бы мы сейчас. Самым близким и формально допустимым оказывался образ мученицы или хотя

25 Dillon. 2002: 200-208. См. также: ФеАин. 2016: 61-64. 


\section{Серегина А.Ю. Жизнеописание леди Фолкленд}

бы женщины, гонимой за веру: он был приемлем, ибо за ним стояла долгая традиция мартирий, но он же позволял самим своим присутствием намекать и на другие роли - наставницы и учительницы 26.

В адресованной женскому кругу читательниц биографии (не предназначавшейся, кроме того, к изданию) сестрам Кэри не было необходимости преуменьшать «миссионерский» аспект деятельности их матери. Леди Фолкленд обращала в католичество словом - об этом свидетельствуют обращения ее детей, а также и пером - она переводила и даже сочиняла полемические тексты, отстаивающие католическое вероучение. Таким образом, она являлась миссионером и страдала (претерпевала гонения) именно за эту деятельность. Ведь описанный в тексте эпизод с допросами был напрямую связан с обращением сыновей и их отъездом в католическую школу.

Необходимыми качествами для миссионера считались интеллект и знания законов божеских и человеческих. И на страницах биографии леди Фолкленд представала перед читателями интеллектуалкой, знакомой с сочинениями отцов церкви и современных богословов и с законами, способной отстаивать свои взгляды и убеждать при помощи разумных доводов.

Более того, подробное описание деятельности матери свидетельствовало как о ее достоинствах, так и о ее познаниях в соответствующих областях - богословии и юриспруденции - ее дочерей-монахинь, которые тем самым тоже косвенно претендовали на статус миссионеров. Казалось бы, о каком миссионерстве могла идти речь применительно к женщинам, заключенным в стенах обители? Однако именно этот образ регулярно использовали по отношению к себе

Серегина. 2013. 
английские монахини. Наиболее распространенным - и общественно приемлемым - было представление монахинь как воительниц за веру, орудием которых становилась постоянная молитва за возврат Англии в католичество. Однако в религиозной культуре английских женских обителей присутствовал и другой образ - миссионеров, наставлявших пером, а именно при посредстве обращенных к единоверцам сочинений и переводов наставительных трудов. И в этом смысле сестер Кэри вполне можно назвать миссионерами: во-первых, все они приняли постриг в обители Камбре, славившейся своими интеллектуальными занятиями: переводами наставительных трудов, а также публикацией средневековых трудов («классики» английского мистического богословия, в том числе и Джулианы Норичской и др.) и изданием собственных сочинений ${ }^{27}$. Во-вторых, они и сами являлись писателями, причем в числе их сочинений была и биография матери - фактически история ее обращения в католичество. Подобные труды - важная часть религиозной культуры XVI-XVIII вв. - среди английских католиков мыслились не только как свидетельства истинности веры обращающегося, но и как инструменты обращения других ${ }^{28}$. Таким образом, сестры Кэри, не выходя из кельи, выступали на миссионерском поприще.

27 Goodrich. 2016.

28 Murrey. 2009: 74-79. 


\section{Список источников и митературы}

\section{Источники}

Chamberlain. 1939 - Letters of John Chamberlain / Ed. by N.E. McClure. Vol. 2. Philadelphia, 1939.

Cary. 1613 - The Tragedie of Miriam, the Faire Queene of Iewry. Written by that learned, virtuous, and truly noble lady E.C. L., 1613. 1630.

Cary. 1630 - Reply of the most Illustrious Cardinal of Perron. [L.],

Cary. 1680 - The History of the Life, Reign and Death of Edward II, or The History of the most Unfortunate Prince, King Edward II. L., 1680.

Simpson. 1861 - The Lady Falkland, Her Life. From a MS. in the Imperial Archives at Lille / Ed. by R. Simpson. L., 1861.

Weller, Ferguson. 1994 - The Lady Falkland, Her Life / Ed. by B. Weller, M. Ferguson. Berkeley, 1994;

Wolfe. 2001 - Elizabeth Cary, Lady Falkland: Life and Letters. / Ed. by H. Wolfe. Temple, Arizona, 2001.

\section{\ИТЕРАТУРА}

Серегина. 2003 - Серегина А.Ю. Смиренная мятежница: обращение в католичество Элизабет Кэри // Адам и Ева. Альманах гендерной истории. Вып. 5. 2003. С. 121-144.

Серегина. 2011 - Серегина А.Ю. Историописание в женских монастырях: «Хроника» конвента Св. Моники (XVII в.) // Адам и Ева. Альманах гендерной истории. Вып. 19. 2011. С. 119-147.

Серегина. 2013 - Серегина А.Ю. Репрезентации женской религиозности и эпистолярные практики в XVII в.: Луиса де Карвахаль и Мэри Уорд // Адам и Ева. Альманах гендерной истории. Вып. 21. 2013. С. 67-87.

Серегина. 2017 - Серегина А.Ю. Английское католическое сообщество XVI-XVII вв.: виконты Монтегю. М.; СПб., 2017.

Серегина. 2018 - Серегина А.Ю. Женская биография и католическая религиозная культура XVII в.: «Жизнеописание леди Монтегю» // Адам и Ева. Альманах гендерной истории. Вып. 26. 2018. C. 226-243.

Серегина. 2019 - Серегина А.Ю. Закон и женщина: английское судопроизводство в «Жизнеописании леди Фолкленд» // 
Электронный научно-образовательный журнал «История». Т. 10. Вып. 10 (84). 2019. [Электронный ресурс]. URL: https://history.jes.su/s207987840007787-4-1/ (дата обращения: 23.11.2021).

Серегина. 2021 - Серегина А.Ю. Обретение голоса. Женщины английского католического сообщества XVI-XVII вв. М.; СПб., 2021. С. 130-147.

Федин. 2016 - Федин А.В. Иезуитская миссия в Новой Франции в первой половине XVII в. М., 2016.

Bolton Holloway. 2004 - Bolton Holloway J. More, Helen // Oxford Dictionary of National Biography online [2004], https://doi.org/10.1093/ref:odnb/19178 (дата обращения: 23.11.2021).

Carlysle, Ibbetson. 2004 - Carlysle E.I., Ibbetson D. Tanfield, Sir Lawrence // Oxford Dictionary of National Biography online [2004], https://doi.org/10.1093/ref:odnb/26959 (дата обращения: 23.11.2021).

Conversions. 2017 - Conversions: Gender and Religious Change in Early Modern Europe / Ed. by S. Ditchfield, H. Smith. Oxford, 2017.

Cooper, Bellenger. 2004 - Cooper T., Bellenger D.A. Fursdon, John // Oxford Dictionary of National Biography online [2004], https://doi.org/10.1093/ref:odnb/10253 (дата обращения: 23.11.2021).

Dillon. 2002 - Dillon A. The Construction of Martyrdom in the English Catholic Community, 1535-1603. Aldershot, 2002.

Fernie. 2004 - Fernie E. Lee, Sir Henry // Oxford Dictionary of National Biography online https://doi.org/10.1093/ref:odnb/16288 23.11.2021).

Goodrich. 2016 - Goodrich J. 'Attend to Me': Julian of Norwich, Margaret Gascoigne and Textual Circulation among the Cambrai Benedictines // Early Modern English Catholicism: Identity, Memory and CounterReformation / Ed. by J.E. Kelly, S. Royal. Leiden, 2016. P. 105-121.

Hodgson-Wright. 2004 - Hodgson-Wright S. Cary, Elizabeth // Oxford Dictionary of National Biography online [2004], https://doi.org/10.1093/ref:odnb/4835 (дата обращения: 23.11.2021). 


\section{Серегина А.Ю. Жизнеописание леди Фолкленд}

Kelsey. 2004 - Kelsey S. Cary, Henry, First Viscount Falkland // Oxford Dictionary of National Biography online [2004], https://doi.org/10.1093/ref:odnb/4837 (дата обращения: 23.11.2021).

Murray. 2009 - Murray M. The Poetics of Conversion in Early Modern English Literature: Verse and Change from Donne to Dryden. Cambridge, 2009.

Rieske. 2015 - Rieske C. Doing the Paperwork: Early Modern Converts, Their Narratives and the (Re)Writing of Religious Lives // The Medieval History Journal. 2015. Vol. 18. P. 404-429.

Shinn. 2018 - Shinn A. Conversion Narratives in Early Modern England: Tales of Turning. Palgrave Macmillan e-publication, 2018, https://www.palgrave.com/gp/book/9783319965765

(дата обращения: 23.11.2021).

Wolfe. 1998 - Wolfe H. Cambrai Imprint on the Life of Lady Falkland // English Benedictine Congregation Symposium. Vol. 16. 1998. P. 1-14.

Wolfe. 2004 - Wolfe H. Cary, Anne // Oxford Dictionary of National Biography online [2004], https://doi.org/10.1093/ref:odnb/105828 (дата обращения: 23.11.2021).

Wolfe. 2006 - Wolfe H. Introduction // The Literary Career and Legacy of Elizabeth Cary, 1613-1680 / Ed. by H. Wolfe. Basingstoke, 2006. P. 1-15. 